\title{
ミミズの筋構造を模した蠕動運動型ロボットの開発
}

\author{
嵯峨 宣彦 ${ }^{* 1}$ ，手銭 聡 ${ }^{* 2}$ ，佐藤 俊之 ${ }^{* 3}$, 永瀬 純也 ${ }^{* 4}$ ，遠藤 匠 $^{* 5}$
}

\section{Development of peristaltic crawling robot which imitates muscle structure of an earthworm}

\author{
Norihiko SAGA $^{* 1}$, Satoshi TESEN ${ }^{* 2}$, Toshiyuki SATO ${ }^{* 3}$, Jun-ya NAGASE*4 and Takumi ENDO ${ }^{* 5}$

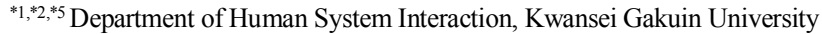 \\ 2-1 Gakuen, Sanda-shi, Hyogo 669-1337, Japan \\ ${ }^{* 3}$ Department of Machine Intelligence and Systems Engineering, Akita Prefectural University \\ 84-4 Aza Ebinokuchi, Tsuchiya, Yurihonjo-shi, Akita 015-0055, Japan \\ ${ }^{* 4}$ Department of Mechanical and Systems Engineering, Ryukoku University \\ 1-5 Yokotani, Setaoecho, Otsu-shi, Shiga 520-2194, Japan
}

Received: 27 November 2017; Revised: 10 February 2018; Accepted: 6 April 2018

\begin{abstract}
In disaster areas, rescue work by humans is extremely difficult and dangerous. Therefore, rescue work using rescue robots in place of humans is attracting attention. This study specifically examines peristaltic crawling, the movement technique used by earthworms, because it can enable movement through narrow spaces and because it can provide stable movement even in various difficult environments. Moreover, we designed each part of the robot based on required specifications and developed a real robot. We present results of motion experiments conducted with robot movement on level ground.
\end{abstract}

Keywords : Peristaltic crawling robot, Biomimetics, FEM analysis, Strength calculation, Mobile robot

\section{1. 緒言}

近年，ロボットを使ったレスキュー活動に注目が集まっており，この利点として災害現場における火災などの 二次災害による被害を抑えられることや，人間が侵入不可能な場所へ移動し，探索・救助を行えることなどが挙 げられる(Tadokoro, 2009). 特に，狭く複雑な空間を深くまで侵入することができるロボットの開発が行われてお り，移動の際に必要な空間の少ないロボットの開発が期待される(伊藤他, 2009), (Harihara et al., 2010).

現在，レスキューロボットの移動機構として，車輪機構(和田他, 2004) (Ito and Maruyama, 2016)，クローラ機構 (Nagatani et al., 2007)，(神村, 2009)，蛇行機構(Hirose and Yamada, 2009)，(Takemori et al., 2016)，螺旋運動機構(Hirose et al., 1999)，多脚機構(伊藤，松野，2002)，摩擦を利用した機構(Bertetto and Ruggiu, 2001)，折り紙などを用いた蛇 腹機構(Onal et al., 2012) 等の様々な機構の開発が行われている. 車輪機構は, 整地における移動効率が高いが, 地面との摩擦が充分でないと滑りや後退が発生し，転倒する可能性がある．また，車輪上に体節が搭載されるこ とが多く，上方向の空間を必要と寸る．また，オムニホイールのような自由度の高い機構では，動作パターンが 複雑化する．クローラ機構は不整地においても，クローラが地面に接することにより，柔軟に地形に対応して移 動することが可能である．しかし，機構が複雑であり，車輪と同様に，上方向の空間を必要とし，重心位置が高 くなることにより，姿勢の安定性に欠ける，蛇行機構は，体軸に沿って正弦曲線を描くように蛇行する機構であ り，不整地の突破性が高い。しかし，蛇行時に体軸のくねり角が小さくなると，蛇行運動が吸収され有効な推力 を発生できないことや，横滑りが発生することもある．螺旋運動機構は，管内移動のための構造が遊星歯車など からなる Whole Stem Drive 機構を有し複雑な機構である. 多脚機構は自由度の高さから様々な歩行パターンの生

No.17-00548 [DOI:10.1299/transjsme.17-00548], J-STAGE Advance Publication date : 18 April, 2018

*1 正員, 関西学院大学 (T669-1337 兵庫県三田市学園 2-1)

$*_{2}$ 関西学院大学 (現 三菱電機 (株))

*3 正員, 秋田県立大学 機械知能システム学科（†015-0055 秋田県由利本荘市土谷字海老ノ口 84-4）

*4 正員, 龍谷大学 理工学部 機械システム工学科（干520-2194 滋賀県大津市瀬田大江町横谷 1-5）

*5 関西学院大学

E-mail of corresponding author: saga@kwansei.ac.jp 
成が可能であり，呪長性から故障に対する而性を持つ。しかし，構造が複雑化し，ロボットの移動に必要な空間 が大きくなる.ささに，重量が重くなることにより，安定性が悪くなる.

これらの機構は不整地の突破性や移動効率の良さという利点を持っているが，狭小な瓦檁内や配管内を自由に 移動するという目的に対しては, 不向きであると考えられる. そこで, 本研究では, 移動に必要な空間の少なさ, 姿勢の安定性, 移動パターンの単純さから, ミミズの移動機構である蠕動運動に着目した. 蠕動運動は我々が早 期から注目していた移動機構であり, この機構を用いたモータ駆動のロボットの開発を行っている (手銭他 2012).

ミミズは，多くの細長い体節が連続して繋がった構造を持ち，その内側は図 1(Fretter and Graham, 1976)のよう に, 体の長手方向に沿う縦走筋と円周方向に沿う環状筋の二層の筋肉によって囲まれている. この筋肉の収縮に よって体節の太さを変えることが可能であり, 体節を膨張させ, 壁面や地面に接触することにより, 体の一部を 固定する保持という動作を行い, 後退波を作り出し前進寸る(土屋他, 1999), (江淵他, 2002). したがって, ミミズ は自身の体が侵入可能な隙間であれば，前進可能となるため，移動に必要な空間が少ない，また，移動の際には 筋肉の膨張により, 体の一部を固定するため, 安定した姿勢を保つことが可能である. さらに，ミミズは体節円 周上のどの面が地面と接触している場合にも蝡動運動可能であるという特徴であり, 姿勢の変化に伴い運動機能 が劣化する “転倒” の心配がない. 体節の伸縮のみを利用して前進する特徵から, 複雑な機構を必要としないこ とも利点として挙げられる.

本研究の目的はミミズの特徵を活かした蠕動運動型ロボットを製作することである. 従来の蠕動運動型ロボッ トの駆動方式の説明及び問題点の提示を行い, それらを解決するための蠕動運動型ロボットの新機構の提案を行 う。 また, エルボ管のような曲管に対応して走行することを想定し, 既存の新日本非破壊検查株式会社より市販 されている内径 $\phi 350 \sim 600 \mathrm{~mm}$ の連続的変化に対応可能なエルボマスター(依田他, 2014) と同等以上の性能を目 指しており, 体節を繋ぐ関節には自由度の高い設計を行う. 各部品に対し, 要求仕様を定義し, 実際のロボット を製作し，管内での前進移動・上昇移動の実験を行ったため，これを報告する.

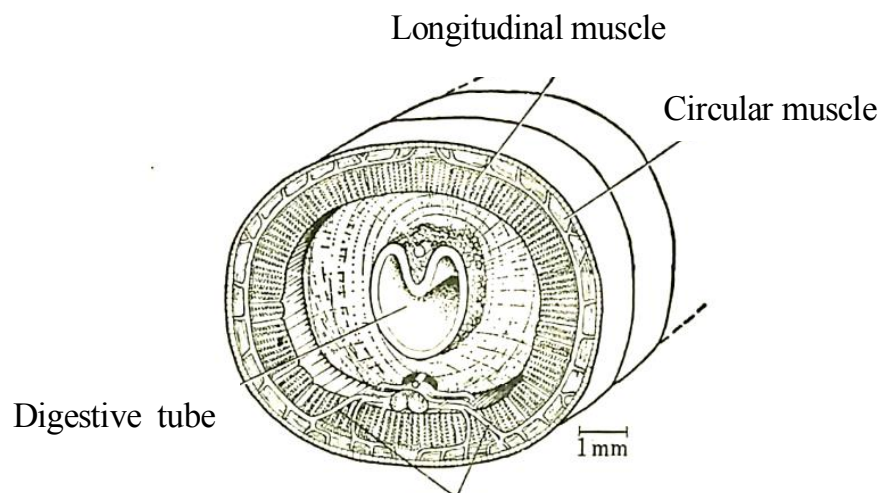

Segmental nerve

Fig.1 Muscle structure of earthworm (a)

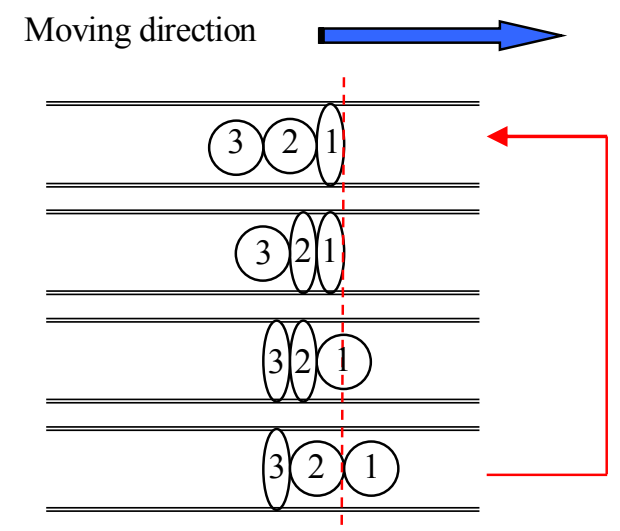

Fig.2 Movement pattern of earthworm

\section{2. 蠕動運動の移動方法}

ミミズは一列に並んだ多くの体節から成り，体の長軸に沿って伸縮波が伝わることにより，前進運動を行って 移動する.ミミズの運動原理を簡易モデルにて表したものを図 2 に示す．例えば，(b)から(c)への過程を例に挙げ ると，(b)では第 1 節と第 2 節が膨張し，壁面に接触することにより保持を行う。ここから(c)へ移行する際には第 1 節が収縮し，それと同時に第 3 体節が膨張寸る．この時，第 2 節は変化しないため保持を継続している．これ により，(b)から(c)への移行では第 1 節の伸びた分だけ前進することになる.この移動パターンからミミズは最低 3 体節あれば移動可能であることが分かる. このように体節の膨張箇所が前方から後方へと波のように移動して いく後退波によって前進している. 


\section{3. 蠕動運動型ロボットの概要}

\section{$3 \cdot 1$ 蠕動運動型ロボット開発の現状}

これまで，蠕動運動を行うロボットの駆動方式として，空気圧を利用した人工筋アクチュエータ(Saga and Nakamura, 2004), (嵯峨他，2005), (則次，久保田，2000), 磁性流体(Saga and Nakamura, 2002), 形状記憶合金(Kim et al., 2006), (篠原他, 1999), (高橋他，1995), (Seok et al., 2013), モータ(Omori et al., 2008)等が挙げられる. 前述の通り, 蠕動運動では筋肉による体節の収縮により，体軸方向の伸縮と円周方向の伸縮の 2 種類の伸縮を行っており，従 来の蠕動運動型ロボットの多くは，この機構を実現するため，単一のアクチュエータの駆動により，体節を球状 に膨張させる機構を採用している．現在，我々の製作している蠕動運動型ロボットは災害地での活動を目的とし ているため, 応答性が高く, 無線化可能である点から, モータ駆動のロボットを開発している. 我々が先行研究 にて開発したロボットも，1 種類のモータの駆動によって 2 方向の伸縮を実現していた.

\section{$3 \cdot 2$ 従来の蠕動運動型ロボットの課題}

これまでに説明したロボットにおける問題点は，体節の伸縮を単一のアクチュエータにて実現していることか ら，体軸方向の伸縮と円周方向の膨張がリンクしていることとなる．したがって，狭小な空間においては膨張量 が少なくなり，それに伴い伸縮量も少なくなるため， ロボットの移動量が低下寸ることである．これは，狭小空 間の移動を想定している蠕動運動型ロボットにおいて，解決すべき問題である.

\section{$3 \cdot 3$ 蠕動運動型ロボットの新機構の提案}

以上から, 本研究にて製作するロボットは, 保持を行う円周方向の伸縮と, 移動を行う長手方向の伸縮のため に 2 種類のアクチュエータを用いる機構を提案する. 保持機構にはサーボモータを利用し, 移動機構にはリニア アクチュエータを利用することとする.

この機構を採用することによる利点として, ロボットの移動距離がリニアアクチュエータの伸縮によって決定 するため, 移動する空間の大小に関係なく一定の移動距離を獲得可能であることと, 保持機構と移動機構が独立 しているため, 多くの体節で保持を行いつつ移動が可能であるため, 動作の安定性が向上寸ると考えられる.

\section{$3 \cdot 4$ 蠕動運動型ロボットの新機構の提案}

本研究にて製作する蠕動運動型ロボットの全体の構造を図 3 に示す．ロボットを構成する主な部品は 3 つ分 けることができ，「体節」，「バッテリ・マイコン搭載部」「「体節間を繋ぐ関節」と呼称する．ミミズは一部の体節 が機能しなくなった場合にも, 最低 3 体節が機能すれば蠕動運動を行える特徵からバッテリ・マイコン搭載部は 伸縮を行わない体節として，体節の中央に他体節と同じサイズにて配置している．また，ロボットはバッテリ・ マイコン搭載部を中心に左右対称な機構とし，体節数は 4 体節とする.これは前進・後退の際に同様の動作を可 能にするためである.さらに，1つの体節は円筒形状でその断面は回転対称の安定な構造とし，ワイヤレスの無 線と自走による走行を可能とする．バッテリはリチウムイオン 2 次電池を想定した機構となっているが，評価実 験は電源に接続して実施した.

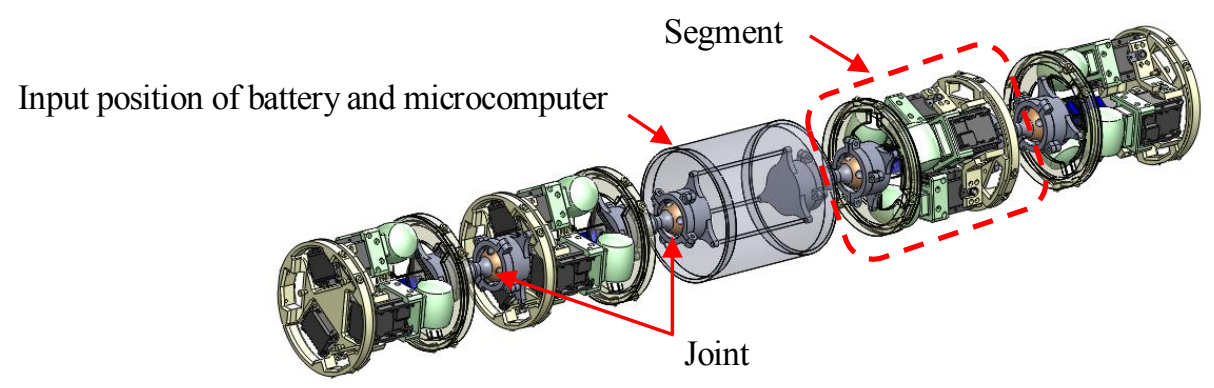

Fig.3 Segmental structure of the peristaltic crawling robot 


\section{$3 \cdot 5$ ロボットの保持機構}

ミミズが移動の際に行う保持の機構を，本ロボットにてどのように実現するかを説明する．ロボットの 1 体節 には 3 つのサーボモータ Dynamixel RX-28(ROBOTIS 製)と 1 つのリニアアクチュエータ L12-I(Firgelli 製)が搭載 されている. サーボモータは体節円周上に等間隔に 3 つ配置してあり, この配置により, 蠕動運動の特徴である, 体節円周上のどの面が地面と接触している際にも，蠕動運動が可能である機構を実現している，平地を走行する 際には下方 2 点による保持を行い，管内を走行する際には 3 点による保持を行う。また， 3 個所のモータはそれ ぞれ独立して動作させることが可能である.

また，保持部の材質として，ABS Plus 樹脂(Stratasys 製)を使用する. ABS Plus 樹脂の摩擦係数は参照値として 0.3 とする. 樹脂面では保持の際の摩擦が少ないと考え, 接触箇所にシリコーンゴムの突起物を付着させることと した. シリコーンゴムの摩擦係数は参照值として 0.5 とする.

\section{4. 蠕動運動型ロボットの設計}

\section{$4 \cdot 1$ ロボット体節の寸法}

本研究にて製作するロボットは，配管内での点検作業を目的としており，さらに東日本大震災で問題となった 原子力発電所の配管内デブリの回収作業も視野に入れている. そこで, 発電所や化学プラントで使用されている 配管の内径として， $\phi 200 \mathrm{~mm}$ 配管内を移動することを目的として， ロボットの寸法を決定する. 特に，曲管の中 でも移動の空間が少ない $\mathrm{T}$ 字管を進行できることを目標とする． T字管をロボットが進行する際，進行不可能と なる条件は, 図 4 に示寸ようにロボットが斜めにつかえてしまう場合である. 以上から，1 体節の対角線の長さ が，配管の内径を超えないことを条件として，式(1)を満たすように設計を行った.

$$
200>L_{t}=\sqrt{L_{w}^{2}+L_{\ell}^{2}}
$$

ここで, $L_{t}: 1$ 体節の対角線の長さ $\mathrm{mm}, L_{w}: 1$ 体節の横幅 $\mathrm{mm}, L_{\ell}$ : 関節間の距離 $\mathrm{mm}$ とする. 式(1)を満たす 寸法として，ロボットの横幅 $120 \mathrm{~mm}$ 以下，関節間の距離 $160 \mathrm{~mm}$ 以下と定義した． $L_{\ell}$ を関節間の距離と定義し た理由は，ロボットは関節部のみ曲げられるため，関節間を 1 つの剛体と見なしているためである.

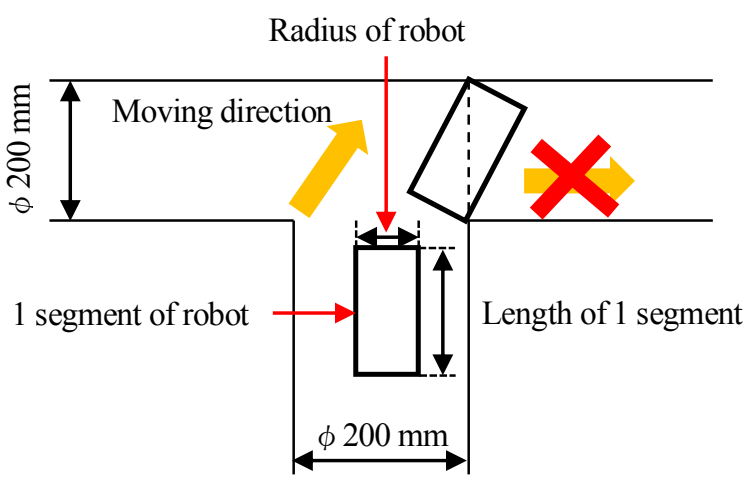

Fig.4 The case which robot clogs up

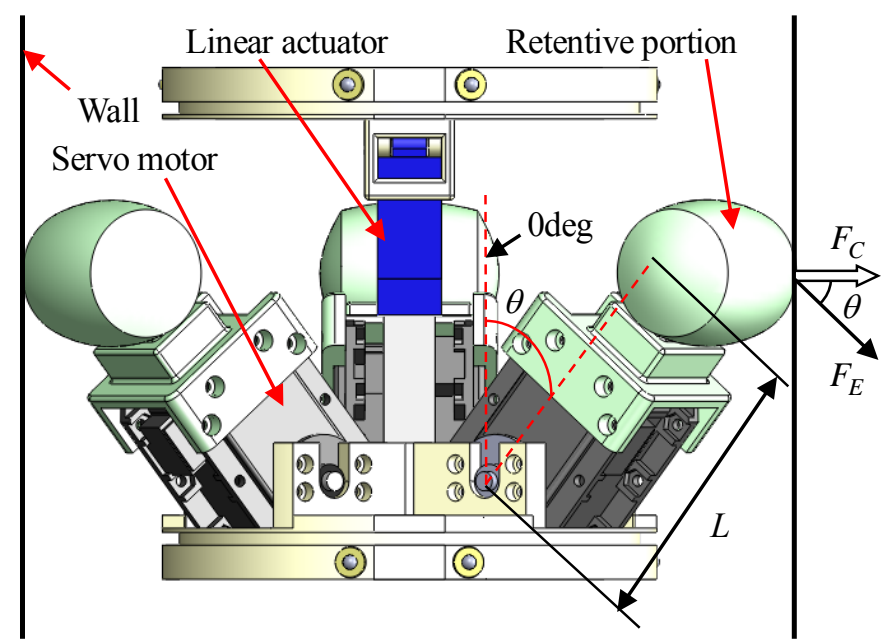

Fig.5 Retentivity model of the robot (1 segment)

\section{$4 \cdot 2$ サーボモータの選定について}

本研究では，配管内にてロボットが上昇運動を行うことを想定している．したがって，モータは上昇運動を行 うために，十分な保持力を発揮可能なトルクを持つことを要求仕様とする. ここで，保持力とは，ロボットが保 持動作によって壁面と接触した際に，体節を固定するための力である. 保持力がロボットの自重よりも大きけれ 
ば，体を支えることができ，上昇運動可能になると考えられる．以下では，保持力と自重の関係式の導出を行う. 実際の上昇運動の際には, 他体節にて保持を行うことを想定しているが, 本研究では, 動作の安定性を向上させ るため, モータの故障等により，1体節のみにて保持を行った場合を想定して式の導出を行う.

上昇運動を行う際の保持力モデルを図 5 に示寸. $T$ : サーボモータのトルク $\mathrm{N} \cdot \mathrm{mm}$ とし， $L:$ モータの回転軸 から保持部までの長さ $\mathrm{mm}$ とする. $F_{E}$ : モータの回転軸から $L \mathrm{~mm}$ 伸びた先で発生する力 $\mathrm{N}$ は式(2)によって表 すことができる.

$$
F_{E}=\frac{T}{L}
$$

$\theta$ : 保持を行うためにモータを回転させる角度 $\operatorname{deg}$ とし，体節が収縮している状態を角度 $0 \operatorname{deg}$ とする. $\theta$ の值を大きくすると, 保持部は壁に近づくこととなる. 保持部が接触した際の, $F_{C}: 1$ つのサーボモータが 壁を垂直に押す力 $\mathrm{N}$ は式(3)のように表すことができる.

$$
F_{C}=F_{E} \cdot \cos \theta
$$

さらに， $\mu$ : 保持部と壁との最大静止摩擦係数を考慮し，ロボットは管内で 3 点保持を行うため, P : 体を支え る保持力として発揮できる最大の力 $\mathrm{N}$ は式(4)のように表せる.

$$
P=3 F_{C} \cdot \mu
$$

$M$ : 自重 $\mathrm{N}$ は各体節・バッテリ・マイコンの重量を考慮し, それに $S$ : 安全率を乗じたものを, $\mathrm{R}:$ ロボットの重 量 N とすると，式(5)のように表せる.

$$
R=M \cdot S
$$

以上から，上昇運動を行うためには式(6)を満たす必要がある.

$$
P>R
$$

ここで, $L=65.0 \mathrm{~mm}, \quad \theta=50 \mathrm{deg}, \mu=0.5, S=2$ とする. L は式(1)にて求めた寸法の条件に収まる長さとして定義 し, $\theta$ は $200 \mathrm{~mm}$ 配管において, $\mathrm{L}$ の長さにて保持を行った際の角度である. また, 安全率として, 保持の際の 接触が半分程度になった際にも保持力が得られることを条件に $S=2$ とした. 以上の条件を満たすモータを選定し た結果, 重量が $0.7 \mathrm{~N}, 18.5 \mathrm{~V}$ 時にトルク $\mathrm{T}=3628 \mathrm{~N} \cdot \mathrm{mm}$ であるサーボモータ $\mathrm{RX}-28$ を使用することにより, 式 (6)を満たすことから，上昇運動を行うための十分な保持力が得られると考えられる.

\section{$4 \cdot 3$ リニアアクチュエータの選定について}

上昇運動の際には，リニアアクチュエータの推力によって体節を持ち上げる動作を行う必要がある. リニアア クチュエータは, 軽量であること, 1 体節を持ち上げられること, ストローク長が式(1)で求めた関節間の距離を 超えないことを要求仕様とし, 選定を行った.

1 体節の重さをモータと $\mathrm{ABS}$ 樹脂の重さから $5.0 \mathrm{~N}$ とし，これを押し上げ可能な推力を持つリニアアクチュエ 一タを選定した結果, 垂直方向の推力が $12.0 \mathrm{~N}$ となるリニアアクチュエータ L12-I を使用することとした. また, このアクチュエータのストローク長は $30.0 \mathrm{~mm}$ である.

\section{$4 \cdot 4$ 保持部の設計}


保持部とは，保持を行う部品であり，ロボットは壁面との接触により保持を行う機構のため，保持の際には大 きな負荷がかかることが想定される。したがって, 保持部を設計する際には FEM 解析により強度計算を行い, 外 形や寸法を決定することとした.

部品の設計には 3DCAD ソフト SolidWorks を用いており, 前述の通り, ABS Plus 樹脂により製作する. 使用し た 3D プリンタの Stratasys 社から提供された ABS Plus 樹脂の降伏強さは $28.0 \mathrm{MPa}$ であったことから, 今回の試 作評価に耐え得る発生応力を半分となる $14.0 \mathrm{MPa}$ を許容応力として強度設計する.

次に, FEM 解析における解析条件について定義する. 式(3)からも分かるように, モータの回転角度が小さい程 壁面を押寸力は大きくなる，したがって，保持部に最も負荷がかかる条件は，モータの回転角度が $0 \operatorname{deg} の$ 際に 保持を行い，壁面を押している場合である. モータの回転軸から保持部までの長さは $65.0 \mathrm{~mm}$ と定義しており， モータのトルクは $3628 \mathrm{~N} \cdot \mathrm{mm}$ であるため, 保持部が壁面を押寸力はおよそ $56.0 \mathrm{~N}$ となる. 保持部が壁面から受 ける反力も $56.0 \mathrm{~N}$ となり, これが保持部にかかる負荷となる. 以上から, 拘束条件として, ねじ穴 8 か所を固定 すること，荷重条件として，保持部に対して，接触面から垂直に $56.0 \mathrm{~N}$ の力が発生することとする.

上記の条件の下，試行錯誤的に外形を変化させ，許容応力以下となるよう外形を検討した結果，最終的に得ら れた結果を図 6 に示寸. 最大発生応力は $8.4 \mathrm{MPa}$ であり, 保持の際には部品の強度は充分であると考える.

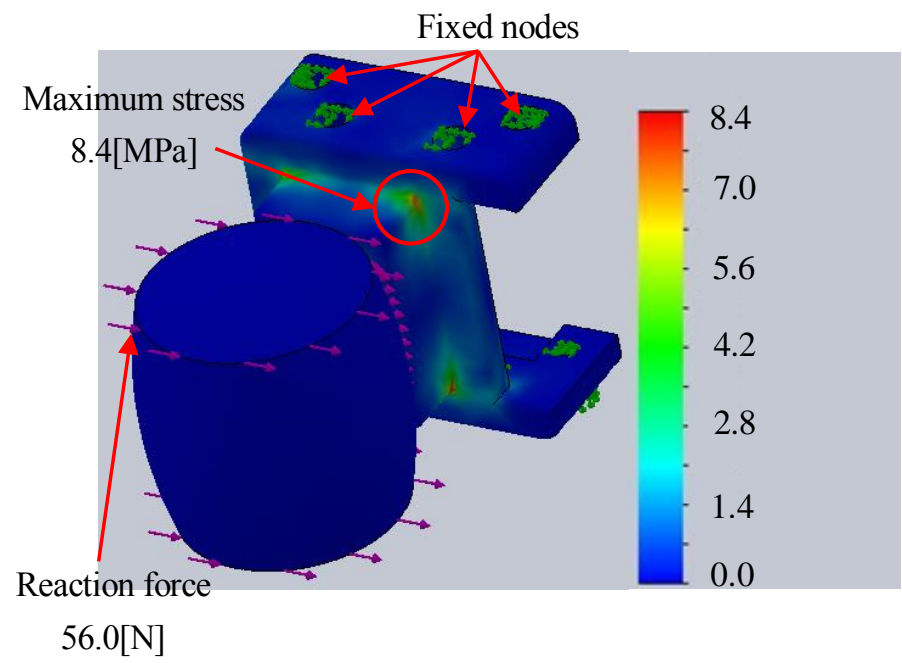

Fig.6 Result of FEM analysis of retentive portion

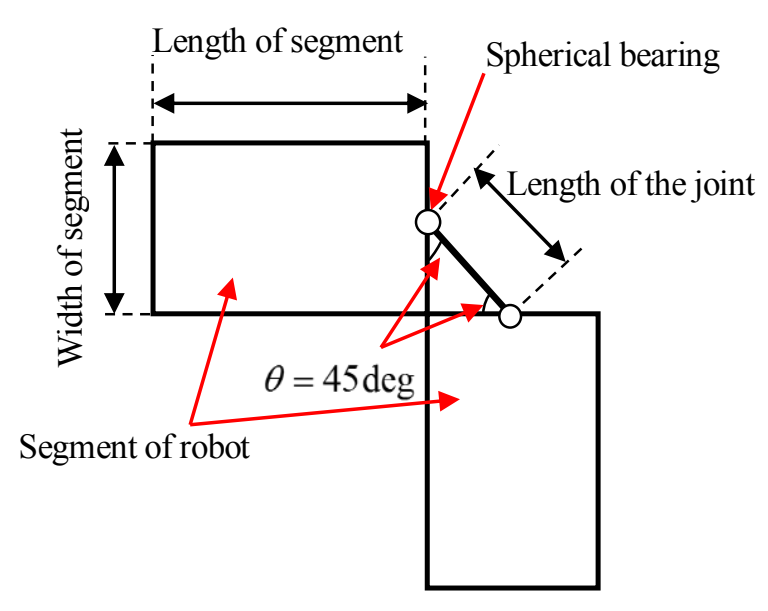

Fig.7 Derivation of the joint length

\section{$4 \cdot 5$ 体節間を繋ぐ関節の設計}

ミミズの特徴として, 体節円周上のどの面が地面と接触している際にも蠕動運動が可能であることが挙げられ る. この機構を実現するため, 関節は口ボットが転倒等により, 地面との接触面が変化した場合にも, 任意に曲 げられる必要がある. 本研究における関節は, 全方向への可動を実現するため, 球面軸受を用いた受動関節を用 いることとした.

また, 曲管を移動することを想定し, 関節の可動域は $90 \mathrm{deg}$ 程度であることとする. しかし, 球面軸受の欠点 は可動範囲の少なさであり, 機構上 $90 \mathrm{deg}$ の屈曲を行うことは不可能である. この問題を解決するため, 本研究 では, 球面軸受を 2 繋げた機構を採用した. この機構により, 単体の球面軸受は可動域が士 $45 \mathrm{deg}$ 程度あれば, 二つを組み合わせることにより, 最大可動域 $\pm 90 \mathrm{deg}$ を実現可能となる. 関節の長さに関する要求仕様は, ロボッ トが関節を $90 \mathrm{deg}$ 屈曲させた際に, 前後の体節が接触しないことであり, これは体節の横幅から式(7)のように求 めることが可能である. この式をモデル化したものを図 7 に示す.

$$
L_{J}=\frac{L_{w}}{2} \times \frac{1}{\cos \theta_{J}}
$$

ここで, $L_{J}$ : 関節の長さ $\mathrm{mm}, L_{w}$ : 体節の横幅 $\mathrm{mm}, \theta_{J}$ : 体節に対する関節の傾き角度 $\operatorname{deg}$ である. 体節の横 幅を $120 \mathrm{~mm}$ と定義したため, その值を式(7)に代入すると, 関節長さは $85.0 \mathrm{~mm}$ 以上であればよいことが分かる. 


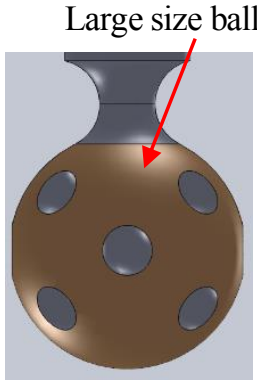

(a) Shape of large size ball

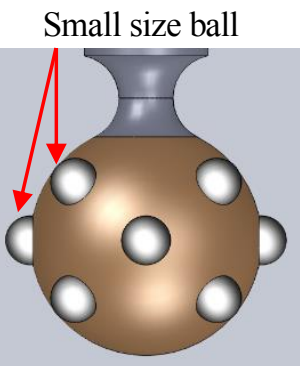

(b) Placement of small size ball

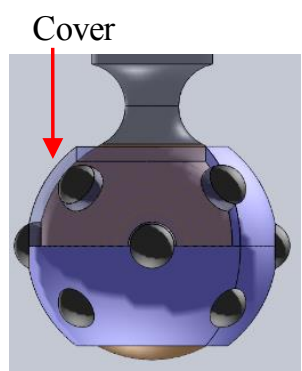

(c) Installation of cover

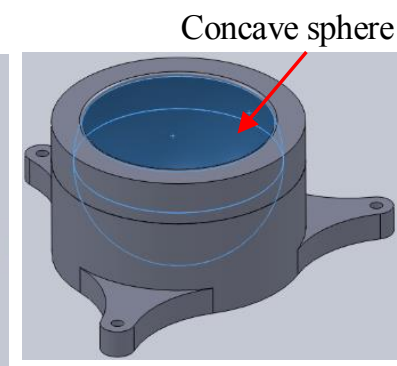

(d) Shape of concave sphere

Fig. 8 Parts which constitutes spherical bearing

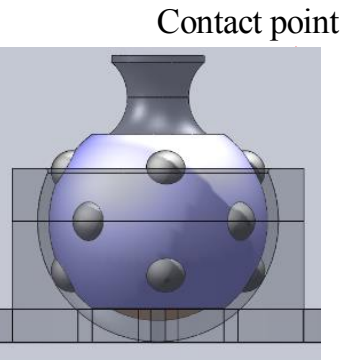

(e) Contact of small size ball and concave sphere

球面軸受を設計する上で，機構は球面軸受 SRJ(ヒーハイスト製)の構造を参考とした．球面軸受を構成する部 品を図 8 に示し, 組み立てる順番に部品の説明を行う。(a)に示す大球が球面軸受の根幹となる部品であり，外側 の軸と連結している. (b)に示す大球にボールが入るような窪みを持たせ, その窪みに図のように小球を配置する. 次に，(c)のように，大球周りにスペーサのようにカバーを取り付けることにより，ボールがこぼれ落ちないよう にする.ここで，小球以外の部品は ABS Plus 樹脂を用いて製作しており，大球とカバーは ABS 樹脂同士を接着 可能なアセトンを用いて接着した. 大球とカバーに挟まれたボールはどちらとも接着することなく，スムーズに 回転することが可能である.さらに軸受の外装を(d)に示す. 内装は凹球面になっており, 大球が入ることにより， 軸受内部の接触は(e)のように, 大球とボールの接触及びボールと凹球面の接触となり, 転がり軸受のような機構 をえることができ。摩擦を軽減することが可能となる，また，ボールの材質として，軽量で硬度が高く，耐摩耗 性に優れたセラミック球を使用することとした.

\section{$4 \cdot 6$ 新機構蠕動運動型ロボットの製作}

以上の部品を組み合わせることにより製作した蠕動運動型ロボットの全体図を図 9 に示す. ロボットの制御に は H8 マイコンを使用しており，各アクチュエータへの配線はロボット内部の空洞を通るように設計しており， ロボットの伸縮動作を妨げないような構造となっている. 試作したロボットの仕様を表 1 に示す.

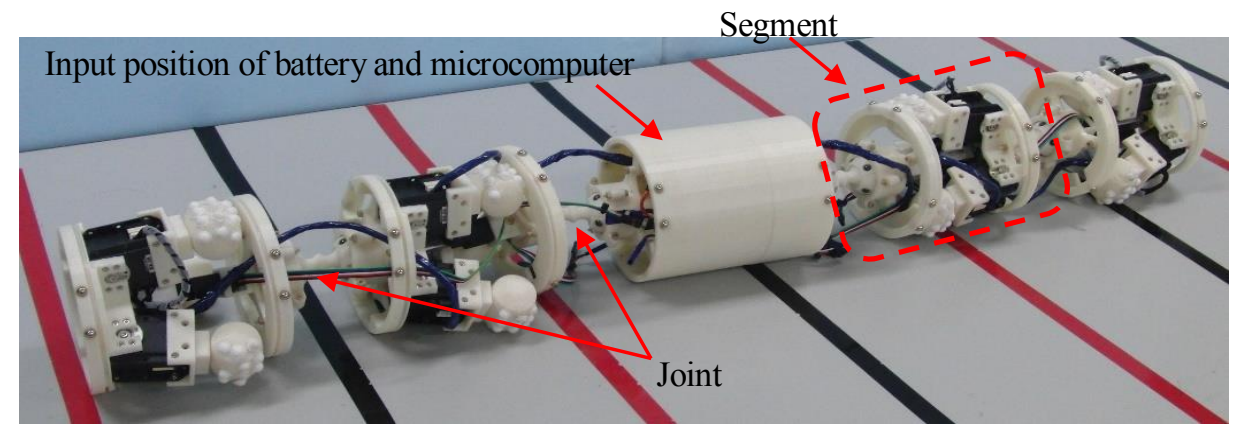

Fig.9 Overall view of real robot 
Table1 Specifications of prototype robot

\begin{tabular}{c|c}
\hline Total length $[\mathrm{m}]$ & $1.245(\mathrm{Min}) \sim 1.365(\mathrm{Max})$ \\
\hline Minimum radius [m] & 0.116 \\
\hline Length of 1 segment [m] & 0.135 \\
\hline Weigt of 1 segment [kg] & 0.05 \\
\hline Intersegmental distance $[\mathrm{m}]$ & 0.0855 \\
\hline Adaptable minimum radius of pipe $[\mathrm{m}]$ & 0.2 \\
\hline
\end{tabular}

\section{5. 蠕動運動型ロボットの移動パターンの検討}

\section{$5 \cdot 1$ 移動パターンの定義}

蠕動運動の機構は多体節から構成され, 各体節の動作によって様々な移動パターンを作り出すことができると 考えられる. 研究室の先行研究では, 強化学習というアルゴリズムを用いてモータのみを用いた蠕動運動型ロボ ットの，最速移動パターンを検討してきた．これから得られたパターンを応用し， 2 種類のアクチュエータを用 いた移動パターンとして $2 つ の$ 移動方法を定義する. 最も移動距離を獲得することが可能な「最速モード」, 最も 姿勢が安定した状態で進行可能な「安定モード」の 2 つを定義し，その詳細を示す．さらに本ロボットの特徵の 一つである体節のモータを独立に動作可能であることを利用した，平地動作についても合わせて説明を行う。

ロボットの移動パターンを表現するために, 図 10 に示寸ようなロボットの簡易的な 2 次元モデルを使用し, 移動中のアクチュエータの動きを検討する.ロボットの進行方向を図の右側とし，その方向のロボットヘッドを 先頭とする．体節の呼称は先頭から体節 1 , 体節 2 , 体節 3, 体節 4 と定義する.

黒丸はサーボモータを示しており，本来は 1 体節に 3 個使用しているが，モデルの簡易化のために 2 個のみ表 示している．白丸は保持部であり，これが壁面と接触することにより，「保持」が行われ，保持を行っている体節 はその位置に固定される. 二重丸は体節間を繋ぐ関節を示している. サーボモータは保持部を壁面方向に回転さ せ，リニアアクチュエータは体節を押し込むもしくは引き寄せる動作を行う.

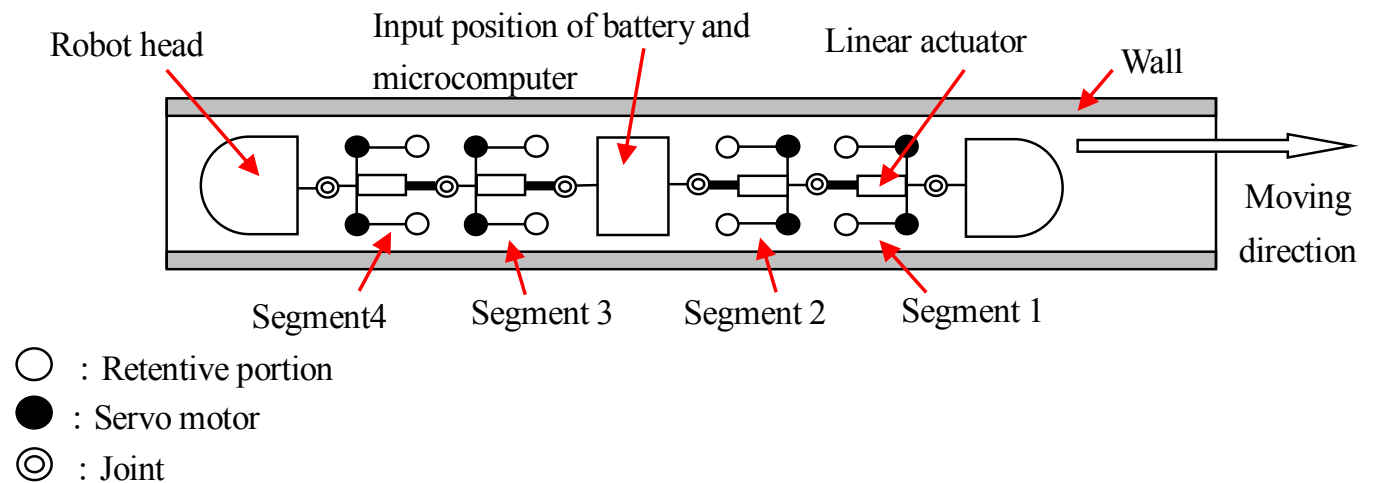

Fig.10 Simplified model of the robot

\section{$5 \cdot 2$ 最速モ一ドについて}

研究室での先行研究の結果から, 蠕動運動の移動では先頭と最後尾の体節は保持動作のために利用される体節 であり，中央の体節は移動のために利用される体節であることが判明している．これは中央の体節が複数ある場 合でも同様であり，複数の体節を合わせて 1 つの体節と見なし，同時に動作させることにより同じ動きが得られ る. 図 10 を例にすると，体節 1 が先頭の体節であり，体節 2,3 が中央の体節，体節 4 が最後尾の体節となる.

最速モードの動作パターンを，簡易モデルを用いて表したものが図 11 である. (a)を初期状態とし，(b) では体 節 4 が保持を行い，(c)にて全てのリニアアクチュエータを伸展させる. そして，(d)では体節 1 が保持を行い，体 節 4 の保持を解除する. (e)のように全てのリニアアクチュエータを収縮させることにより，後方の体節が先頭に 
引き寄せられ，移動を行う。これまでの動作が蠕動運動の 1 周期となり，(e)の次は(b)の動作のように，体節 4 を 保持させ, 体節 1 の保持を解除する. 全てのリニアアクチュエータを同時に動かすことで, 最大の移動量を獲得 することができ，この動作パターンが蠕動運動型ロボットの最速移動パターンとなる．また体節を，バッテリ搭 載部を中心に左右対称に配置している理由は, リニアアクチュエータを対にして搭載することにより, 伸展方向 と逆方向に発生する対抗力を打ち消し合うためである.

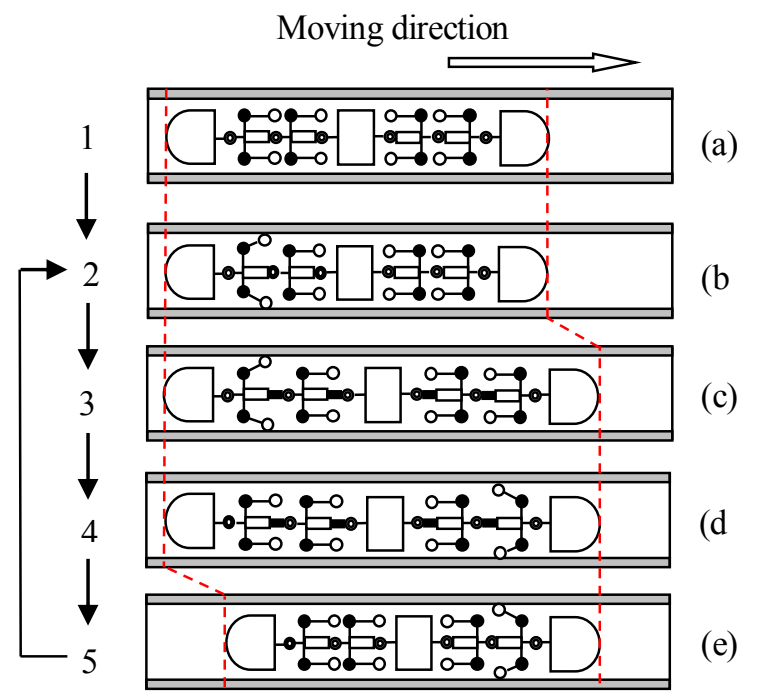

Fig.11 Movement pattern of fastest mode

\section{$5 \cdot 3$ 安定モードについて}

これまで，最速モードでは中央の体節を 1 つ体節として捉え，同時に動かしていたが，安定モードでは全て の体節を 1 つずつ動作させ，後退波を作り出す，蠕動運動により近い動作を行わせる.

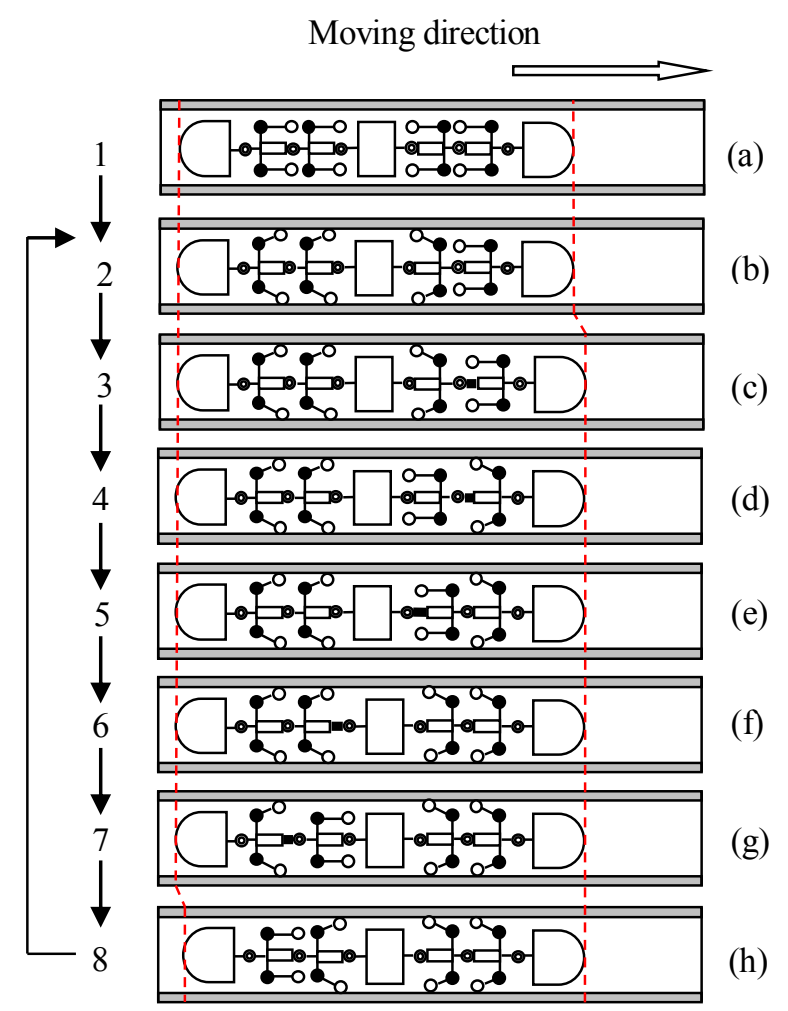

Fig.12 Movement pattern of stability mode 
安定モードの動作パターンを，簡易モデルを用いて表したものが図 12 である. (a)を初期状態とし，(b)にて体 節 1 以外の全ての体節が保持を行い，(c)にて体節 1 のリニアアクチュエータが伸展する. 次に，(d)のように体節 1 が保持を行い，体節 2 が保持を解除寸る. (e)で体節 1 のリニアアクチュエータを収縮させると同時に，体節 2 のリニアアクチュエータを伸展させる．同様に(f)は体節 2 の収縮と同時に，体節 3 が伸展，(g)は体節 3 の収縮と 同時に体節 4 が伸展を行う。(h)で体節 4 の収縮を行うことで, 移動を行う.

このモードでは，動作を行っている体節以外の体節が全て保持状態となり，ボディの安定が最も高いモードで ある. 特にこのモードは上昇運動を行う際に有効であると考えられる.

\section{6. 動作実験}

\section{6・1 管内走行実験}

始めに，管内における最速モードでの動作実験を行った．実際の動作の様子とその際の時間と移動距離の関係 をグラフ化したものを図 13 に示す.この移動距離はロボットの最後尾の移動距離を測定したものであり, 移動が 行われていない部分は最後尾の体節が保持をしており，先頭の体節が移動している時である．ロボットの移動は リニアアクチュエータのみに依存しており, 管径が変化した場合でも, 一定の移動距離を獲得することが可能で あると考えられる。
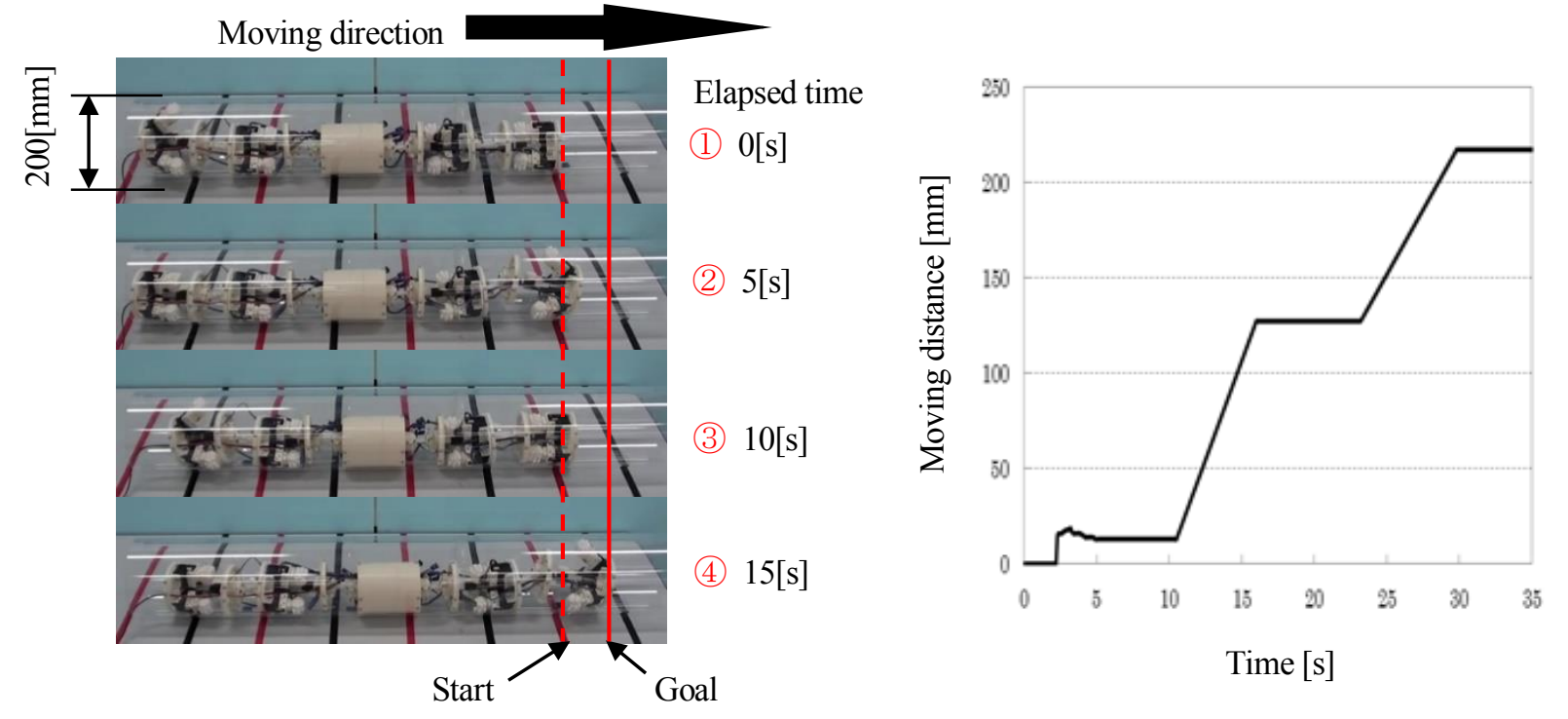

Fig.13 Movement of real robot in pipe

\section{$6 \cdot 2$ 垂直管内走行実験}

次に，垂直管内において上昇運動の動作実験を行った．垂直管内を移動する際には安定モードを利用するこ とにより，複数の体節にて保持を行い，移動を行うこととした．実際の動作の様子を図 14 に示寸.

\section{Elapsed time}

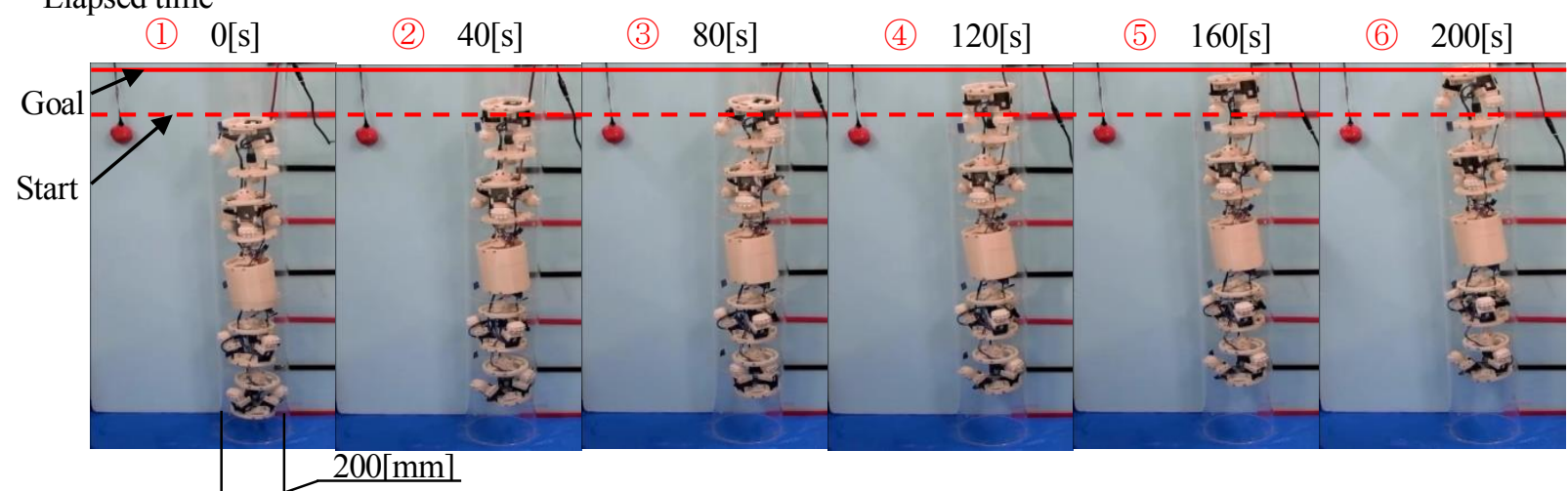

Fig.14 Movement of real robot in pipe 


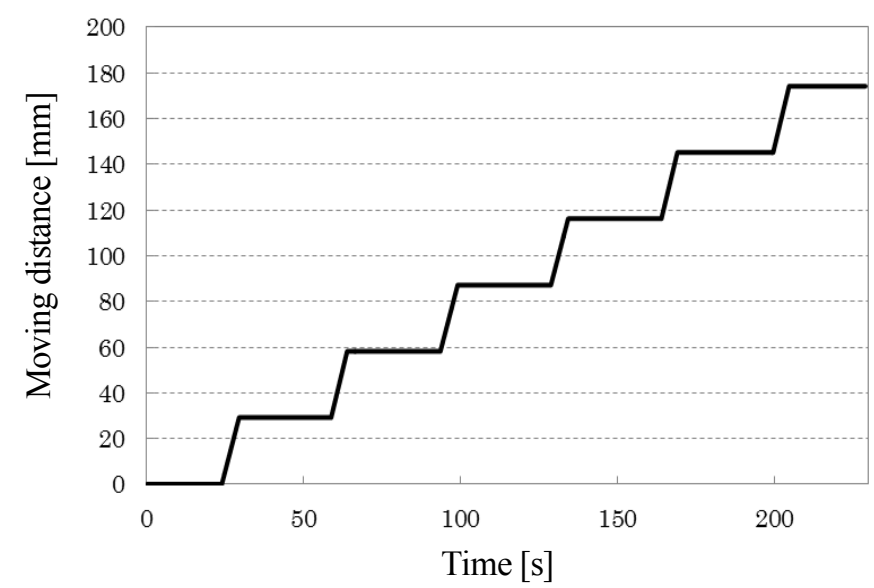

Fig.15 Moving distance of real robot in perpendicular pipe

その際の時間と移動距離の関係をグラフ化したものを図 15 に示す. 図に示寸ように, サーボモータの保持動作に よって体節を保持することができ,リニアアクチュエータの押し上げ動作によって前進可能であることが分かる.

\section{$6 \cdot 3$ 曲管内走行実験}

想定している走行環境である $200 \mathrm{~mm}$ 径の配管にて曲管を作成し, 動作実験を行った. 曲管内移動においては, 最速モードにて動作させている. 実際の動作の様子を図 16 に示寸. 蠕動運動の特徴の 1 つである, 後方の体節が 前方の体節を押し込むことで進行を行っていることが分かる.
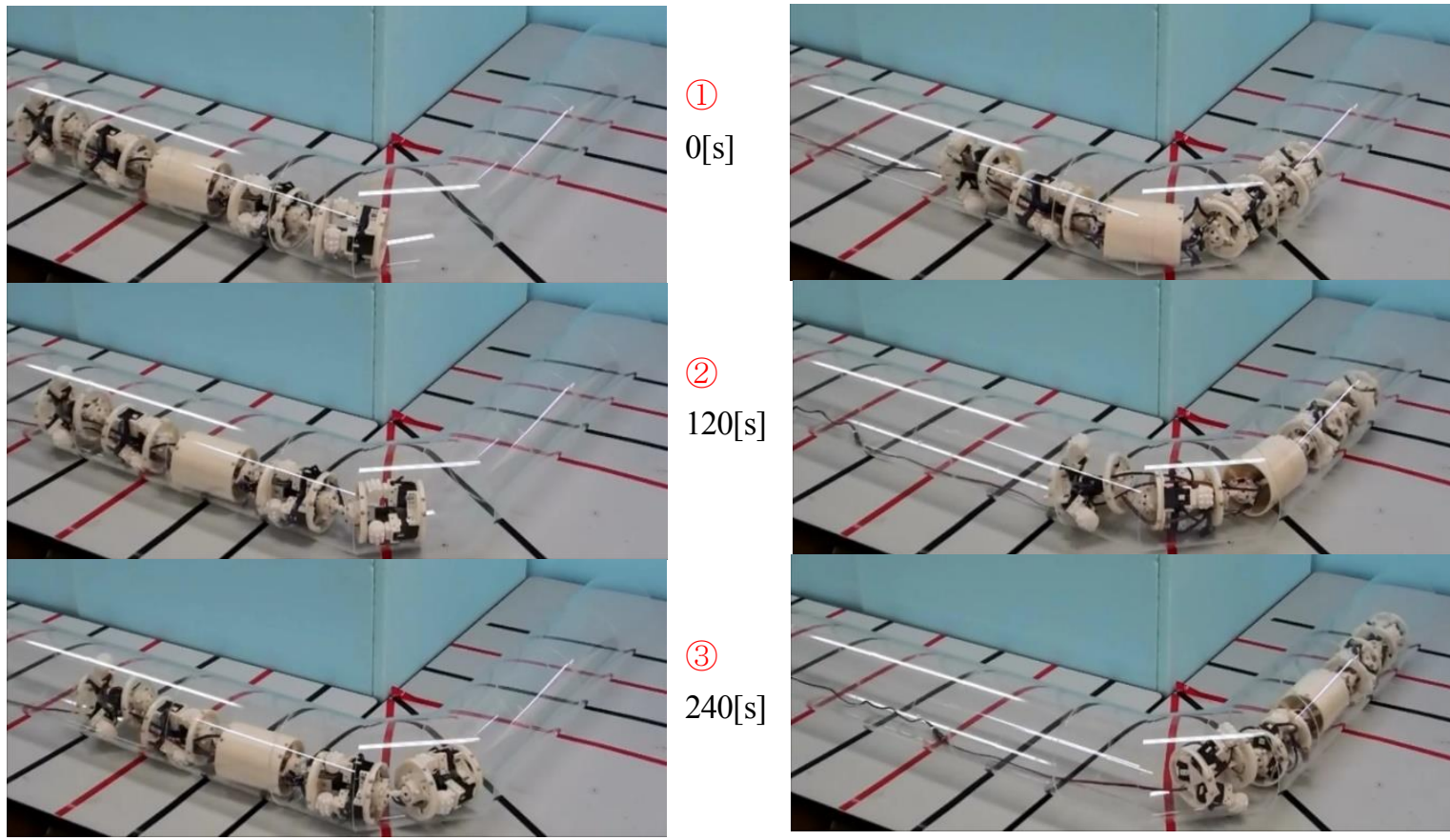

\section{(4)} $360[\mathrm{~s}]$

Fig.16 Movement of real robot in elbow pipe

\section{7. 結言}

本研究では, 蠕動運動型ロボットにおいて, 狭小な空間においても常に一定の移動距離を獲得可能な機構の提 案を行い, 本ロボットでの移動パターンを検討し，実ロボットに実装することによって動作実験を行った．以下 に本研究で得られた結果を示寸. 
始めに，曲管を移動可能であることを条件に体節の寸法を決定した．また，保持力と自重の関係式を求め，ア クチュエータの選定を行った. 保持によって発生する負荷を求め, 部品が降伏しないことを条件に強度計算を行 い，保持部の形状を決定した．以上の条件よりロボットの体節を構成する部品を設計することができる．体節間 を繋ぐ関節は，全方向に可動できることを条件に球面軸受を採用した.

次に新機構の蠕動運動型ロボットによって得られる有用な移動パターンについて検討した. 3 種類の移動方法 として, 最も移動距離を獲得可能な「最速モード」, 最も姿勢が安定した状態で進行可能な「安定モード」を定義 した。これらのパターンによって常に一定の移動距離を獲得可能であることが分かった．また，サイズは $\phi 200$ $\mathrm{mm}$ の曲管(エルボ管)を想定して設計したが，曲管内走行実験で設計通り走行可能であることを確認できた.

ロボットには H8 マイコンを搭載し, 実際のロボットにて上記の移動モードを実現した. 最速モードを利用し た配管内移動，安定モードを利用した垂直管内移動の動作確認を行い移動可能であることが分かった.

今後の課題として, 体節のカバーの装着を検討している. 現在のロボットは 3 方向のみの保持を行っているが, カバーの膨張を利用し, 全方向への保持を確保可能な機構を検討している. 保持部が伸縮する動作を行うため, ラテックスのような高い伸張性を持つ素材を検討する必要があると考えられる．またカバーを装着することによ り防水や配線収納の効果もあると考えられる.

また, ロボットは今後, 分岐のある配管での進行を想定している. ロボットの先頭に, 進行方向を決定するた めのロボットヘッドという機構を装着する予定であり, その内部には距離センサやカメラ等を搭載する予定であ る. これらの機器は配管内部の状況を把握するだけでなく, 障害物がロボットの正面に現れた際の判断にも使用 可能であると考えられる. 特に, 分岐管においては距離センサを用いて, より深い方へ進行するというアルゴリ ズム等を組むことにより配管内における自律的な移動パターンを作ることができると考えられる.

\section{文献}

Bertetto, A. M. and Ruggiu, M., In-pipe inch-worm pneumatic flexible robot, IEEE/ASME International Conference on Advanced Intelligent Mechatronics (2001), pp.1226-1231.

江淵智浩, 土屋学, 前野隆司, 山崎信寿, 波動伝播に基づく移動機構の研究 (第 3 報, 柔軟生物の構造・環境・移 動パターン), 日本機械学会論文集 C 編, Vol.68, No.667 (2002), pp.920-926.

遠藤玄, 外川圭司, 広瀬茂男, 索状能動体に関寸る研究 ーシステムの自立化と対地適応推進一, 日本ロボット学 会誌, Vol.18, No.3 (2000), pp.419-425.

Fretter, V. and Graham, A., A functional anatomy of invertebrates, Academic Press, Fig.79-C (1976), p.227.

Harihara, K., Dohta, S., Akagi, T. and Zhang, F., Development of a search type rescue robot driven by pneumatic actuator, SICE Annual Conference (2010), pp.1311-1317.

Hirose, S. and Yamada, H., Snake-like robots, IEEE Robotics \& Automation Magazine (2009), pp.88-98.

Hirose, S., Ohno, H., Mitsui, T. and Suyama, K., Design of in-pipe inspection vehicles for $\varphi 25, \varphi 50, \varphi 150$ pipes, IEEE International Conference on Robotics and Automation (1999), pp.2309-2314.

伊藤一之, 松野文俊, QDSEGA による多足ロボットの歩行運動の獲得, 人工知能学会論文誌, Vol.17, No.4-B (2002), pp.363-372.

伊藤一之, 村井亮一, 中道和也, 操作性を考慮したへビ型レスキューロボットの開発，日本ロボット学会誌, Vol.27, No.4 (2009), pp.419-426.

Ito, K. and Maruyama, H., Semi-autonomous serially connected multi-crawler robot for search and rescue, Advanced Robotics, Vol 30, Issue 7 (2016), pp. 489-503.

神村明哉, 高段差乗り越え可能なクローラロボット機構, 日本機械学会論文集 C 編, Vol.75, No.758 (2009), pp.138145.

Kim, B., Lee, M., Lee, Y., Kim, Y. and Lee, G., An earthworm-like micro robot using shape memory alloy actuator, Sensors and Actuators A: Physical, Vol.125, Issue 2 (2006), pp.429-437.

Nagatani, K., Endo, D. and Yoshida, K., Improvement of the odometry accuracy of a crawler vehicle with consideration of slippage, Proceedings of the International Conference on Robotics and Automation (2007), pp.2752-2757.

則次俊朗, 久保田充彦, 空気圧ソフトアクチュエータを用いた管内移動ロボットの開発, 日本ロボット学会誌, Vol.18, No.6 (2000), pp.73-80. 
Omori, H., Hayakawa, T. and Nakamura, T., Locomotion and turning patterns of a peristaltic crawling earthworm robot composed of flexible units, International Conference on Intelligent Robots and Systems (2008), pp.1630-1635.

Onal, C., Wood, R. and Rus, D., An origami-inspired approach to worm robots, Transactions on Mechatronics (2012), pp.1-9.

嵯峨宣彦, 上田晋也，中村太郎，人工筋アクチュエータを用いた蠕動運動型ロボットの開発，計測自動制御学会論 文集, Vol.41, No.12 (2005), pp.1013-1018.

Saga, N. and Nakamura, T., Elucidation of propulsive force of micro-robot using magnetic fluid, Journal of Applied Physics, Vol.91, No.10, Parts 2 and 3 (2002), pp.7003-7005.

Saga, N. and Nakamura, T., A prototype of peristaltic robot using pneumatic artificial muscle, Intelligent autonomous system, Vol.8, No.1 (2004), pp. 85-95.

Seok, S., Onal, C. D., Cho, K., Wood, R. J., Rus, D. and Kim, S., Meshworm: a peristaltic soft robot with antagonistic nickel titanium coil actuators, Transactions on Mechatronics (2012), pp.1-13.

篠原英司，南和幸，江刺正喜，ミミズのような蠕動運動システム，電気学会論文誌 E, Vol.119, No.6 (1999), pp.334339.

Tadokoro, S., Rescue robotics (2009) pp.1-16, Springer-Verlag London.

高橋昌樹, 林嚴, 岩附信行, 鈴木康一, 黄木昇, みみずの運動を応用した細管内移動マイクロロボットの研究,精密 工学会誌, Vol.61, No.1 (1995), pp.90-94.

Takemori, T., Tanaka, M. and Matsuno, F., Gait design of a snake robot by connecting simple shapes, IEEE International Symposium on Safety, Security, and Rescue Robotics (2016), pp.189-194.

手銭聡，嵯峨宣彦，池田篤政，佐藤俊之，Q-learning と負荷センサを用いた蝡動運動型ロボットに関する研究，設計 工学, Vol.47, No.3 (2012), pp.38-44.

土屋学，前野隆司，山崎信寿，波動伝播に基づく移動機構の研究 (第 2 報，体節の変形を考慮した細長動物の構造 モデル），日本機械学会論文集 C 編, Vol.65, No.636 (1999), pp.3328-3335.

和田慎, 大屋勝敬, 本田英己, 小林敏弘, 大川不二夫, 車輪型ロボットの不整地面ロバスト走行制御, 日本機械学 会論文集 C 編, Vol.70, No.699 (2004), pp.226-233.

依田誠子，服部康彦，今川幸久，配管検査技術の紹介，日本海水学会誌，Vol.68, No.2 (2014), pp.57-62.

\section{References}

Bertetto, A. M. and Ruggiu, M., In-pipe inch-worm pneumatic flexible robot, IEEE/ASME International Conference on Advanced Intelligent Mechatronics (2001), pp.1226-1231.

Ebuchi, T., Tsuchiya, M., Maeno, T. and Yamazaki, N., Frictional driving mechanism based on wave propagation (3rd report, relationship among structure, environment and locomotive pattern of soft creatures), Transactions of the Japan Society of Mechanical Engineers, Series C, Vol.68, No.667 (2002), pp.920-926 (in Japanese).

Endo, G., Togawa, K. and Hirose, S., Study on self-contained and terrain adaptive active cord mechanism, Journal of the Robotics Society of Japan, Vol.18, No.3 (2000), pp.419-425 (in Japanese).

Fretter, V. and Graham, A., A functional anatomy of invertebrates, Academic Press, Fig.79-C (1976), p.227.

Harihara, K., Dohta, S., Akagi, T. and Zhang, F., Development of a search type rescue robot driven by pneumatic actuator, SICE Annual Conference (2010), pp.1311-1317.

Hirose, S. and Yamada, H., Snake-like robots, IEEE Robotics \& Automation Magazine (2009), pp.88-98.

Hirose, S., Ohno, H., Mitsui, T. and Suyama, K., Design of in-pipe inspection vehicles for $\phi 25, \phi 50, \phi 150$ pipes, IEEE International Conference on Robotics and Automation (1999), pp.2309-2314.

Ito, K. and Matsuno, F., Applying QDSEGA to the multi legged robot, Journal of the Japanese Society for Artificial Intelligence, Vol.17, No.4-B (2002), pp.363-372 (in Japanese).

Ito, K., Murai, R. and Nakamichi, K., Development of snake-like rescue robot designed for ease of use, Journal of the Robotics Society of Japan, Vol.27, No.4 (2009), pp.419-426 (in Japanese).

Ito, K. and Maruyama, H., Semi-autonomous serially connected multi-crawler robot for search and rescue, Advanced Robotics, Vol 30, Issue 7 (2016), pp. 489-503.

Kamimura, A., A crawler robot mechanism enabling high-step climbin, Transactions of the Japan Society of Mechanical Engineers, Series C, Vol.75, No.758 (2009), pp.138-145 (in Japanese).

Kim, B., Lee, M., Lee, Y., Kim, Y. and Lee, G., An earthworm-like micro robot using shape memory alloy actuator, Sensors and Actuators A: Physical, Vol.125, Issue 2 (2006), pp.429-437. 
Nagatani, K., Endo, D. and Yoshida, K., Improvement of the odometry accuracy of a crawler vehicle with consideration of slippage, Proceedings of the International Conference on Robotics and Automation (2007), pp.2752-2757.

Noritsugu, T. and Kubota, M., Development of in-pipe mobile robot using pneumatic soft-actuator, Journal of the Robotics Society of Japan, Vol.18, No.6 (2000), pp.73-80 (in Japanese).

Omori, H., Hayakawa, T. and Nakamura, T., Locomotion and turning patterns of a peristaltic crawling earthworm robot composed of flexible units, International Conference on Intelligent Robots and Systems (2008), pp.1630-1635.

Onal, C., Wood, R. and Rus, D., An origami-inspired approach to worm robots, Transactions on Mechatronics (2012), pp.1-9.

Saga, N., Ueda, S. and Nakamura, T., Development of peristaltic crawling robot using artificial muscle actuator, Transactions of the Society of Instrument and Control Engineers, Vol.41, No.12 (2005), pp.1013-1018 (in Japanese).

Saga, N. and Nakamura, T., Elucidation of propulsive force of micro-robot using magnetic fluid, Journal of Applied Physics, Vol.91, No.10, Parts 2 and 3 (2002), pp.7003-7005.

Saga, N. and Nakamura, T., A prototype of peristaltic robot using pneumatic artificial muscle, Intelligent autonomous system, Vol.8, No.1 (2004), pp. 85-95.

Seok, S., Onal, C. D., Cho, K., Wood, R. J., Rus, D. and Kim, S., Meshworm: a peristaltic soft robot with antagonistic nickel titanium coil actuators, Transactions on Mechatronics (2012), pp.1-13.

Shinohara, E., Minami, K. and Esashi, M., Peristaltic motion system like earthworm, IEEJ Transactions on Sensors and Micromachines, Vol.119, No.6 (1999), pp.334-339 (in Japanese).

Tadokoro, S., Rescue robotics (2009) pp.1-16, Springer-Verlag London.

Takahashi, M., Hayashi, I., Iwatsuki, N., Suzumori, K. and Ohki, N., The development of an in-pipe microrobot applying the motion of an earthworm, Journal of the Japan Society for Precision Engineering, Vol.61, No.1 (1995), pp.90-94 (in Japanese).

Takemori, T., Tanaka, M. and Matsuno, F., Gait design of a snake robot by connecting simple shapes, IEEE International Symposium on Safety, Security, and Rescue Robotics (2016), pp.189-194.

Tesen, S., Saga, N., Ikeda, A. and Sato, T., Peristaltic crawling robot using Q-learning with load sensor, Journal of Japan Society for Design Engineering, Vol.47, No.3 (2012), pp.38-44 (in Japanese).

Tsuchiya, M., Maeno, T. and Yamazaki, N., Frictional driving mechanism based on wave propagation (2nd report, model of earthworm-like structure considering deformation of the body), Transactions of the Japan Society of Mechanical Engineers, Series C, Vol.65, No.636 (1999), pp.3328-3335 (in Japanese).

Wada, M., Oya, M., Honda, H., Kobayashi, T. and Ohkawa, F., Robust control of wheeled mobile robot moving on rough surface, Transactions of the Japan Society of Mechanical Engineers, Series C, Vol.70, No.699 (2004), pp.226-233 (in Japanese).

Yoda, Y., Wakibe, Y. and Imagawa, Y., Inspection method of piping, Bulletin of the Society of Sea Water Science, Japan, Vol.68, No.2 (2014), pp.57-62 (in Japanese). 